\title{
Increasing Social Entrepreneurship Village-owned enterprises (BUMDEs)
}

\author{
Iyan Setiawan ${ }^{1 *}$ Disman $^{2}$ Sapriya $^{2}$ Elly Malihah ${ }^{2}$
}

\author{
${ }^{1}$ Kuningan University, Indonesia \\ ${ }^{2}$ Indonesia University of Education, Indonesia \\ ${ }^{*}$ Corresponding author. Email: setiawaniyan111@gmail.com
}

\begin{abstract}
Badan Usaha Milik Desa (BUMDes) as social institutions that play a role in building village economic activities to improve community welfare. The purpose of this study was to examine the effect of entrepreneurial attitudes, subjective norms, and training to improve social entrepreneurship in BUMDes. The type of research used is quantitative research with the research population of all the heads of BUMDes in Kuningan district. The sample of this study use a population research sample or a total sample, namely the head of BUMDes, totaling 138 respondents. Data were collected through structured questionnaires and then processed using multiple linear regression analysis methods with SPSS program. The results showed that entrepreneurial attitudes, subjective norms, and training had a significant effect of $22.6 \%$ in increasing social entrepreneurship for BUMDes. The influence of other variables outside the model $(\varepsilon)$ is $77.4 \%$ which affects the social entrepreneurship of the BUMDes. This research study contributes to the development of the social entrepreneurship literature and provides opportunities for further research to reveal other variables.
\end{abstract}

Keywords: entrepreneurial attitudes, subjective norms, training, social entrepreneurship, BUMDEs.

\section{INTRODUCTION}

Social entrepreneurship has a global impact in the social sector to help people, especially poverty problems, through innovative steps will be able to solve growing social problems $[11,24]$ Social entrepreneurs play a role in making social change by taking business opportunities to improve social welfare [28]. They try to keep their business running for social values $[8,31,32]$. This social value activity is aimed at "community development" or "organizations with social goals" [32].

Community development demands the role of a social entrepreneur to build economic activities that are focused on social change and social transformation $[25,27]$. One of the most important factors in the development of village communities, namely the head of BUMDes. The head of BUMDes has a very strategic role in improving social entrepreneurship in Village Owned Enterprises (BUMDes). The ability of a leader will certainly create a strategic entrepreneurial atmosphere [16].

The results of the study of Umi Hidayati [33] concluded that the head of BUMDes was not professional in doing his job, had no experience and had an educational background that was not relevant to their work.

The results of Purnamasari's research [34] in the Karawang District of Indonesia regarding the implementation of BUMDes, identified that there are still weaknesses, namely that the Village Government is not maximally empowering to develop BUMDes, and the BUMDes is not running. These two studies illustrate the low experience, educational background of the head of BUMDes and the weakness of the Village Government in empowering BUMDEs.
The human resource (HR) factor is the main factor in managing BUMDEs, especially a BUMDEs chairman who must have managerial skills in developing social entrepreneurship for BUMDes. This requires a deep understanding of the behavior of the head of BUMDes as well as analyzing what abilities affect social entrepreneurship of BUMDes. Entrepreneurship is influenced by the entrepreneurial knowledge of Francisco Liñan [21], to improve the ability of the head of BUMDes, among others by optimizing entrepreneurship education and training, it is best if business actors are given entrepreneurship training [5]. This is in line with the results of research conducted by Wijaya [38], Kourilsky and Walstad [19], which practically recommend that the development of entrepreneurial behavior in society can be done through entrepreneurship training.

Another factor that is no less important by paying attention to improving the entrepreneurship of BUMDes, is the entrepreneurial attitude and subjective norms of a head of BUMDes in behavior. The behavioral research model uses Theory of Planned Behavior which states that a theory is designed to specifically explain human behavior [1]. Behavioral theory cannot be separated from interest in entrepreneurship, because in this theory is argued that the formation of entrepreneurial behavior is based on belief and evaluation to attitude towards, subjective norms. Entrepreneurial attitude to respond objects consistently both in a state of like or dislike, while subjective norms are individual beliefs about the surrounding environment to follow these norms [12]. 
From previous research which concluded about the lack of experience, the educational background of the head of BUMDes and the weakness of the Village Government in empowering BUMDEs. Because of these differences in results, researchers are interested in reviewing more about entrepreneurial attitudes, subjective norms and training in improving entrepreneurship of BUMDes. This effort was made to develop the overall potential of Village Owned Enterprises (BUMDEs) in improving the welfare of village communities.

\section{THEORETICAL FRAMEWORK}

The multidimensional view of social entrepreneurship has been put forward by many experts. As stated by Dees [11] who views that social entrepreneurship is defined as a process by which citizens build or transform institutions to develop various solutions to social problems. Austin, J., Stevenson, H., \& Wei-Skiern [6] argue that the characteristics of social entrepreneurship include: 1) innovation, which means entrepreneurship is a creative process that uses an opportunity to produce something new, 2) social value creation, where the social objectives of social entrepreneurial activities are clearly stated, and 3) loci which means that social entrepreneurial activities occur in all sectors and their collaborative interactions. In line with this statement, Nicholls [27] states that social entrepreneurship has dimensions: socialibity, market orientation, and innovation. These three dimensions are an integral part of the concept of social entrepreneurship. The social dimension implies that social entrepreneurial activities cannot be separated from activities related to the context of social life, meaning that entrepreneurial activities are intended to achieve social welfare.

The theory developed in social entrepreneurship research uses Theory of Planned Behavior which states that a theory designed specifically explains human behavior [1]. Theory of Planned Behavior (TPB) provides a decision to display certain behavior is the result of a rational process that is directed at a specific goal and follows a sequence of thinking [7]. The main concern in the theory of planned behavior is carrying out a behavior from an attitude or other variables. Entrepreneurial attitude means the degree of acceptance of a person towards entrepreneurship. Attitudes can come from a rational mindset that considers the advantages and disadvantages of being an entrepreneur, both from the economic, personal, social, employment aspects, et cetera. Pakpahan [36] states that attitude is the tendency to act, perceive, think and feel in dealing with objects, ideas, situations or values.

Attitude is needed for entrepreneurial entrepreneurs in order to be able to identify business opportunities, then utilize business opportunities to create new job opportunities. Thus, it can be concluded that in this study, the theory of Ajzen and Fishbein "The Theory of Planned Behavior" in Baron \& Byrne [7] which reveals that entrepreneurial attitudes are one of the important elements that can influence entrepreneurial behavior. Entrepreneurial attitudes can be proven to be predictors that influence entrepreneurial behavior in entrepreneurs
Subjective norms are individual beliefs about the surrounding environment and individual motivation to follow these norms [12]. Subjective norms are views that are considered important by individuals who suggest individuals to do or not do certain behaviors and motivations accompanied by a willingness to do or not do something that is considered important. Subjective norms can influence entrepreneurial actions from the external side in the form of support for the environment, both family, friends and successful entrepreneurs. This perception is subjective, so this dimension is called a subjective norm. Some researchers have found that subjective norms do play an important role in predicting entrepreneurial intentions to behave [18].

Other factors, namely education and training. Entrepreneurship is influenced entrepreneurial knowledge by Francisco Liñán's [21]. Entrepreneurship training is an program or educational process that develops entrepreneurial attitudes and skills [13]. Training is more effective at creating entrepreneurial skills [14]. Kourilsky and Walstad [19] state that the influence of entrepreneurship education has been considered as an important factor for growing and developing entrepreneurial desire, spirit and behavior among the younger generation. The results of research conducted by Wijaya [38], practically recommend that the development of entrepreneurial behavior in society can be through entrepreneurship training. This is in line with the results of research conducted by Wijaya [38], Kourilsky and Walstad [19], which practically recommend that the development of entrepreneurial behavior in society can be done through entrepreneurship training. Entrepreneurship training should be studied as the main tool that supports entrepreneurs in creating and maintaining an entrepreneurial culture to achieve higher performance. Mohammed Ali Al-Awlaqia, Ammar Mohamed Aamer, Nasser Habtoor [26] Entrepreneurship training creates more successful entrepreneurship, especially for newly established businesses such as micro-sized businesses [30].

Based on the aforementioned problems, the conceptual framework that will be used in this study can be presented in Figure 1. Variables of entrepreneurial attitudes, subjective norms, training are considered having an influence on socio entrepreneurship.

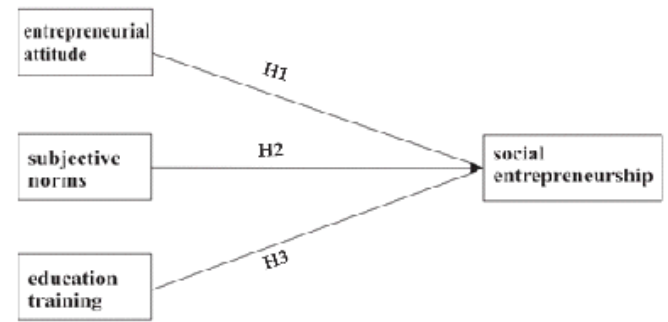

Figure 1 Research Conceptual Framework

Based on the above explanation, the following hypotheses are anticipated. 
Based on the above explanation, the following hypotheses are anticipated.

Hypothesis 1: Entrepreneurial Attitudes partially has a significant effect on Social Entrepreneurship

Hypothesis 2: Subjective Norms partially Hypothesis 3: Entrepreneurship Attitudes, Subjective and Training simultaneously has a significant influence on Social Entrepreneurship

\section{METHOD}

This research is a quantitative research. The population of Village Owned Enterprises (BUMDes) in Kuningan Indonesia district is 138 units. This study used a population sample or a total of 138 heads of BUMDes as respondents. The data used in this study are primary data obtained directly from questionnaires by respondents. The questionnaire contains research instruments measured on a Likert scale.

Methods of data analysis using multiple linear regression analysis to determine the factors that influence social entrepreneurship. The variables used in this study are grouped into two categories, namely the dependent variable and the independent variable. The dependent variable is social entrepreneurship (Y). The independent variables are training (T), Entrepreneurial Attitudes (EA) and Subjective Norms (NS). Data were analyzed using Ordinary Least Squares panel data regression

$\mathrm{Y}=\beta 0+\beta 1 \mathrm{EA}+\beta 2 \mathrm{NS}+\beta 3 \mathrm{~T}+\varepsilon$

Explanation:

$\begin{array}{lll}\mathrm{Y} & = & \text { Social entrepreneurship } \\ \mathrm{EA} & = & \text { Entrepreneurial attitude } \\ \mathrm{NS} & = & \text { Subjective norms } \\ \mathrm{T} & = & \text { Education training } \\ \beta 0 \beta 1 \beta 2 \beta 3 & = & \text { Explanatory coefficient for each input } \\ & \text { parameter Y value }\end{array}$

As a first step before testing the multiple linear regression model), the classical assumption model is tested: normality test, autocorrelation test, and multicollinearity test, then the partial regression coefficient test $t$ test. The $t$ test is used to determine the significant effect of each independent variable on the dependent variable. Then the simultaneous $\mathrm{F}$ test is used to determine the validity of the multiple linear regression model obtained.

\section{RESULT AND DISCUSION}

Normality Test: Data normality testing can be shown through the distribution of data in the P-Plot diagram. In Figure 1 it can be seen that the data distribution is in the range of lines and follows the direction of the diagonal line. This shows that the regression model can be used because it fulfills the classical assumptions

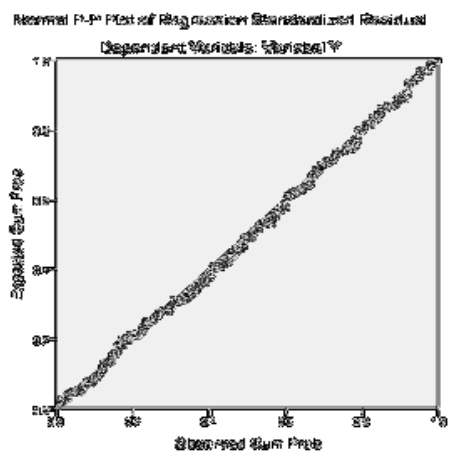

Figure 2 P-Plotdiagram

Autocorrelation test: The autocorrelation test obtained a $\mathrm{DW}$ value of 1.867 . Result $\mathrm{DW}=1,867$. If it is adjusted to the D-W value classification table, the value lies between 1.55 - 2.46; which indicates that there is no autocorrelation. Multicollinearity test: Testing the presence or absence of multicollinearity between independent variables can be seen that the FIV (Variance Inflation Factor) value for the Training variable (T) is 1.482, Subjective Norms (NS) are 1.485, Entrepreneurship Attitude (EA) is 1.166. VIF value shows VIF $<10$, it can be said that there is no multicollinearity.

Table 1 Uji Multikolinieritas

\begin{tabular}{|l|c|c|}
\hline \multicolumn{1}{|c|}{ Model } & Tolerance & VIF \\
\hline Entrepreneurial attitude & .858 & 1.166 \\
\hline Subjective norms & .673 & 1.485 \\
\hline Training & 675 & 1.482 \\
\hline
\end{tabular}

Test of the coefficient of determination (R2): Testing the coefficient of determination R2 $=0.475$ and adjusted R2 of 0.226 . So it can be concluded that $22.6 \%$ of the social entrepreneurship variable of BUMDes is influenced by training, subjective norms, entrepreneurial attitudes while the remaining $77.4 \%$ is explained by other variables not discussed in this study.

\subsection{Partial Hypothesis Testing}

Entrepreneurial attitudes have a significant effect on social entrepreneurship in BUMDes showing a t-statistic value of 2.541 with a significant value $=0.012(0.012<0.05)$ and a statistic of $t 2.541<1.365$ This shows that partially the entrepreneurial attitude variable affects social entrepreneurship. This means that the hypothesis (H1) is accepted.

Subjective norms have a significant effect on social entrepreneurship BUMDes showing a t-statistic value of 2.058 with a significant value $=0.042(0.042<0.05)$ and statistical t $2.058<\mathrm{x}<1.365$. This shows that partially the subjective norm variable affects social entrepreneurship. This means that the hypothesis (H2) is accepted.

Training has a significant effect on BUMDes social entrepreneurship. It shows a t-statistic value of 2.306 with a 
significant value $=0.023(0.023<0.05)$ and the $\mathrm{t}$-statistic is $2.541<1.365$. This shows that partially the training variable has an effect on social entrepreneurship. This means that the hypothesis (H3) is accepted.

Table 2 Hasil Uji Hipotesis Partial

\begin{tabular}{|l|l|l|l|}
\hline Variabel & Standarized Coefficient & t - Statistic & Sig \\
\hline EA & 0.209 & 2.541 & 0.012 \\
\hline NS & 0.191 & 2.058 & 0.042 \\
\hline ET & 0.213 & 2.306 & 0.023 \\
\hline
\end{tabular}

\section{F Test (Simultaneous Hypothesis)}

Based on the ANOVA output, the Sig value is 0.000 and the F statistical value is 13.033 , where the Sig value is $0.000<\alpha$ 0.05 . It means that simultaneously there is a significant influence of entrepreneurial attitudes, subjective norms, training, on social entrepreneurship.

Simultaneous hypothesis testing data on the effect of entrepreneurial attitudes, subjective norms and training on social entrepreneurship are presented in table 3 below

Table 3 Pengujian Signifikansi

\begin{tabular}{|c|c|c|c|c|c|c|}
\hline \multicolumn{2}{|c|}{ Model } & Sum of Squares & df & Mean Square & F & Sig. \\
\hline \multirow{4}{*}{1} & Regression & 348.051 & 3 & 116.017 & 13.033 & $.000^{\mathrm{b}}$ \\
\cline { 2 - 8 } & Residual & 1192.855 & 134 & 8.902 & & \\
\cline { 2 - 8 } & Total & 1540.906 & 137 & & & \\
\hline
\end{tabular}

The entrepreneurial attitude has a significant influence on the social entrepreneurship of BUMDes in Kuningan district. The results showed that there were still heads of BUMDes who had not dared to face risks in managing BUMDes. To overcome this problem, the head of BUMDes is required to have the ability to face risks. This ability is one of the important values in managing social enterprises and is very much determined by their beliefs. The higher the confidence of the Head of BUMDes, the greater the chance to try. In essence, taking risks will like the challenges and opportunities that will be faced.

Social entrepreneurs are agents of change who have criteria, one of them is acting boldly without being limited by existing resources [11]. Entrepreneurs who dare to face risks are people who always want to be winners [37]. Furthermore, the key to success in business is how a person can understand himself. Attitude is the basis in building the psychological characteristics of an entrepreneur. [4]. This study confirms that social entrepreneurship can be improved through attitude. The personality dimension, or in other words, personal traits, is an important factor in determining whether a person can become an entrepreneur [9]. This is in line with this research, Ajzen and Fishbein's theory "The Theory of Planned Behavior" in Baron \& Byrne [7] which reveals that entrepreneurial attitudes are one of the important elements that can influence entrepreneurial behavior.

Subjective norms have a significant influence on BUMDes social entrepreneurship. The results showed that there were still heads of BUMDes who did not fully have high entrepreneurial motivation in accordance with community expectations. To overcome this obstacle, the head of BUMDes is required to have the motivation to match the community expectations, this is greatly influenced by the external environment. The thoughts of other parties are considered important that individuals should or should not display certain behaviors [1]. Negative experiences with entrepreneurship, can pressure not start a business [1]. In essence, the environment is one of the factors that can influence a person's social entrepreneurship which in the end subjective norms will be formed to meet the guidance of the environment. Previous studies confirmed subjective norms as a determinant of the importance of entrepreneurship [3]

Training has a significant influence on social entrepreneurship in BUMDes in Kuningan district. The results showed that there were still heads of BUMDes who did not apply the results of the training they attended in managing BUMDes and had not participated in routine training. In addition, the Head of BUMDes in his activities has not raised the potential of local wisdom as a superior product in the local area. To overcome the aforementioned obstacles, the Head of BUMDes is required to have good entrepreneurial knowledge in managing BUMDes through training. The training that was followed by Head of BUMDes will be better prepared with the challenges and difficulties faced in managing BUMDes. With the implementation of regular, varied and continuous training in its activities, Head of BUMDes can improve his ability, this aspect is very effective in supporting BUMDes entrepreneurship.

This requires a comprehensive policy of Regional Governments, Service, District and Village Governments related. The importance of training for the head of BUMDes to be carried out on an ongoing basis by requiring all management, especially the chairman to attend seminars or workshops, after obtaining provisions from this training should be applied in BUMDes management activities. Entrepreneurial spirit can be carried out through formal education, entrepreneurship seminars and training. Training as a process and a factor for developing talents, desires, souls and behavior among entrepreneurs to increase a person's insight, skills and abilities to complete their work " [22]. Whereas previous research argues that 
entrepreneurship training can increase opportunities to start new businesses [2] The results of Wijaya's [38] research concluded that the development of entrepreneurial behavior in society can be done through training. The novelty of this research is the social entrepreneurship of BUMDes has not raised the potential of local wisdom as a superior product of BUMDes business, the are still problem of the heads of BUMDes who have not been creative in exploring the potential for village local wisdom, this can be seen from the responses of the dimensions of local wisdom and social innovation which are still low. Ideally, the existence of superior BUMDes should develop social entrepreneurship based on the village's original potential by ensuring that all residents participate in its activities. In building BUMDes, a new breakthrough is needed by the head of BUMDes by making social innovations. An entrepreneur as an agent of change must be involved in a continuous innovation process [11].

Social innovation offers solutions to social, economic, environmental problems, and opens up space for people to be creative in generating regional benefits. This is in accordance with the policy of Regional Government Regulation No.38 of 2017 concerning Regional Innovation (Article 2 Paragraph 1 of PP No. 38 of 2017) according to this PP the target is directed to accelerate the realization of community welfare through improving public services, empowerment, and community participation in improving regional competitiveness. With this PP, the role of the head of BUMDes should be able to understand, accept and take advantage of BUMDes social innovations by encouraging the community to be actively involved in achieving social goals. The key to social entrepreneurship is social innovation [10].

\section{CONCLUSION}

From the results and discussion above, in general it can be concluded that entrepreneurial attitudes, subjective norms and training simultaneously have a significant influence on social entrepreneurship in BUMDes. The entrepreneurial attitude of the head of BUMDes should be brave enough to face risks in managing BUMDes. The Head of BUMDes is required to be brave enough to face risks. The ability to face risks is one of the important values for trying out social enterprise opportunities.

The higher the creative and innovative attitude of the head of BUMDes, the greater the opportunity to try. The point is that by taking risks, the head of BUMDes will be challenged to seize opportunities.

Subjective normative is the view of other parties who are considered important by the head of BUMDes to display or not display certain behavior. For this reason, a successful social entrepreneurship role model is needed to carry out a companion program in managing the BUMDes business. This allows the head of BUMDes to have a reference as an amplifier as what he does must be in accordance with community expectations. Then another factor that is no less important, namely training. Training is an effort to improve abilities, knowledge and skills. The head of BUMDes should participate in regular training and apply the results of the training he has attended in managing BUMDes which eventually increases his abilities.

\section{ACKNOWLEDGMENT}

Iyan Setiawan, started his career in 2010 as lecture in Universitas Kuningan. Currently active as a fulltime lecturer at Universitas Kuningan. The area of economic educational. Currently, Iyan Setiawan is continuing his doctoral studies in Social Sciences education at the Indonesian Education University (UPI).

\section{REFERENCES}

[1] Ajzen, I. (1991). The Theory of Planned Behavior. Organizational Behavior Human Decision Processes, 50(2), 179-211. https://doi.org/10.1016/0749-5978(91)90020-T

[2] Afolabi, M. O., Kareem, F. A., Okubanjo, I. O., Ogunbanjo, O. A., \& Aninkan, O. O. (2017). Effect of entrepreneurship education on selfemployment initiatives among Nigerian science \& technology students. Journal of Education and Practice, 8(15), 44-51.

[3] Awang, A., Ibrahim, I. I., \& Ayub, S. A. (2014). Determinants of entrepreneurial career: Experience of Polytechnic students. Journal of Entrepreneurship, Business and Economics, 2(1), 21-40.

[4] Ainul Mohsein Abdul-Mohsina, Hasliza AbdulHalimb, Noor Hazlina. (2012). Delving into the issues of entrepreneurial attitude orientationand market orientation among the SMEs A conceptual paper. International Congress on Interdisciplinary Business and Social Science (ICIBSoS)

[5] Astamoen, M. P. (2008). Entrepreneurship dalam Perspektif Kondisi Bangsa Indonesia. Bandung: Alfabeta.

[6] Austin, J., Stevenson, H., \& Wei-Skiern, J. (2006). Social and Commercial Entrepreneurship : Same, Defferent or Both Entrepreneurship Theory and Practice, 30, 1-22. https://doi.org/10.1111/j.15406520.2006.00107.x

[7] Baron, Robert A. \& Byrne, Donn (2004); alih bahasa, Ratna Djuwita ... [et al.]. Psikologi Sosial. Jakarta: Erlangga.

[8] Brooks, A.C. 2009. Social Entrepreneurship: aModern Approach to Social Venture Cre-ation. Upper Saddle River, NJ: Pearson Education, Inc.

[9] Cheng, M. Y., \& Chan, W. S. (2009). The effectiveness of entrepreneurship education in Malaysia. Education + Training, 555 - 566. doi: 10.1016/j.sbspro.2016.05.413

[10] Drayton, B., \& Falk, J. (2001). Tell-tale signs of the inquiryoriented classroom. NASSP Bulletin, 85, 24-34. doi:10.1177/019263650108562304 
[11] Dees, J. G. (1998). The Meaning Of "Entrepreneurship". File https://Entrepreneurship.Duke.Edu/NewsItem/The-Meaning-Socialentrepreneurship /Drucker, P. F. Innovation Entrepreneurship. California: Perfect Bound.

[12] Feldman, Robert, S. (1992). Elements of Psychology. (International Ed.). San Fransisco: Mc. Graw Hill, Inc.

[13] Fayolle, A., \& Klandt, H. (Eds.). (2006). International entrepreneurship education: Issues and newness. Cheltenham, UK; Northampton, MA: Edward Elgar Pub.

[14] Galvão, A., Ferreira, J. J., \& Marques, C. (2017). Entrepreneurship education and training as facilitators of regional development: A systematic literature review. Journal of Small Business and Enterprise Development, 25 (1), 17-40. https://doi.org/10.1108/JSBED-05-2017-0178.

[15] Gielnik, M. M., Uy, M. A., Funken, R., \& Bischoff, K. M. (2017). Boosting and sustaining passion: A long-term perspective on the effects of entrepreneurship training. Journal of Business Venturing, 32(3), 334-353. https://doi.org/10.1016/j.jbusvent.2017.02.003.

[16] Hitt, M.A., Biermant, L., Shimizu, K., \& Kochhar, R. (2001). Direct and moderating effects of human capital on strategy and performance in professional service firms: A resource-based perspective. Academy of Management journal, 44(1), 13-28.

[17] Ireland, R.D., \& Webb, J. W. (2007). A crossdisciplinary exploration of entrepreneurship research. Journal of management, 33(6), 891-927.

[18] Iakovleva, T., \& Kolvereid, L. (2009). An integrated model of entrepreneurial intentions. International Journal of Business and Globalisation, 3(1), 66

[19] Kourilsky, M.L. \&Walstad, W.B. (1998). Entrepre-Neurship And Female Youth: Knowledge, Attitudes, Gender Differences and Educational Practices. Journal Of business Venturing, 13(1): 77-88.

[20] Kolvereid, L. (1996). Prediction of employment status choice intentions. Entrepreneurship Theory \& Practice, 21(1), 47-57

[21] Liñán, F. (2004). Intention-Based Models of Entrepreneurship Education. PiccollaImpresa/Small Business, 3(12),1-30.

[22] Moekijat. (1991). Evaluasi Pelatihan Dalam Rangka Penigkatan Produktivitas. Bandung: Mandar Maju.

[23] Mc. Clelland. D.C. (1961). The Achieving Society. London: The Free Press.

[24] Mustapha, R., Zapata, V. \& Jung-Kim, J. 2008. Promoting Human Capital through SocialEntrepreneurship: a Comparative Study of
Indonesia and China. Jurnal Pendidikan,33: 6179.

[25] Mair, J., \& Noboa, E. (2006). Social entrepreneurship: How intentions to create a social venture are formed. In Social entrepreneurship (pp. 121-135). UK: Palgrave Macmillan.

[26] Mohammed Ali Al-Awlaqia, Ammar Mohamed Aamer, Nasser Habtoor (2018) The effect of entrepreneurship training on entrepreneurial orientation: Evidence from a regression discontinuity design on micro-sized businesses. The International Journal of Management Education https://doi.org/10.1016/j.ijme.2018.11.003

[27] Nicholls, A. (2006). Playing the Field: A New Approach to the Meaning of Social Entrepreneurship. Social Enterprise Journal, 2.1, pp. 1-5;

[28] Praszkier, R. Nowak, A., et al. (2009). Social Capital Built by Social Entrepreneurship and The Spesipic Traits That Facilitate the Process Psychologis Spoeczna, 42-51.

[29] Roberts, D. \& Woods, C. 2005. Changing theWorld on a Shoestring: The Concept of Social Entrepreneurship. University ofAuckland Business Review, Autumn:45-51.

[30] Runyan, R., Droge, C., \& Swinney, J. (2008). Entrepreneurial orientation versus small business orientation: What are their relationships to firm performance? Journal of Small Business Management, 46(4), 567-588. https://doi.org/10.1111/j.1540627X.2008.00257.x.

[31] Santos, F.M. 2009. A Positive Theory of Social Entrepreneurship. INSEAD Social Innova-tion Centre Working Paper No. 2009 /23 /EFE /ISIC. (Online),

(http://www.insead.edu/facultyresearch/research/ doc.cfm?did=41727), accessed November 10, 2012.

[32] Tan, W., Williams, J. \& Tan, M. 2005. Definingthe 'Social' in 'Social Entrepreneurship': Altruism and Entrepreneurship. International Entrepreneurship and Management Journal, 1 (3): 353-365.

[33] Umi Hidayati (2015). Performance Analysis of Village-Owned Enterprise Managers as a Basic of Designing Education and Training. European Journal of Business and Management. ISSN 22221905 (Paper) ISSN 2222-2839 (Online) Vol.7, No.32, 2015 Hal. $143-147$

[34] Purnamasari., Hanny, dkk. (2016). Efektivitas Pemberdayaan BUMDes Berbasis Ekonomi Kerakyatan di Desa Warung Bambu Kecamatan Karawang Timur Kabupaten Karawang”. Jurnal Politikom Indonesiana 1 (2) 31-42. 
[35] Pemerintah Daerah No.38 Tahun 2017 PP No. 38 tentang Inovasi Daerah Pasal 2 Ayat 1

[36] Pakpahan, Rosma. (2010). Pengaruh FaktorFaktor Fundamental Perusahaan dan Kebijakan Deviden Terhadap Nilai Perusahaan (Studi Kasus Pada Perusahaan Manufaktur Periode 20032007); Jurnal Ekonomi, Keuangan Perbankan dan Akuntansi Vol. 2, No, 2 November 2010, 211-277
[37] Wirasasmita, Yuyun. (1994). Kewirausahaan: Buku Pegangan Jatinangor: UPT-Penerbitan IKOPIN

[38] Wijaya, Tony. (2008). Kajian Model Empiris Perilaku Berwirausaha Ukm DIY dan Jawa Tengah. Jurnal Manajemen dan Kewirausahaan, Vol. 10 No. 2, (Pp: 93 - 104) 